\title{
THE PATHOLOGICAL EFFECTS UPON RATS OF EXCESS IRRADIATED ERGOSTEROL ${ }^{1}$
}

By ALFRED T. SHOHL, HARRY GOLDBLATT AND HELEN BENNETT BROWN

(From the Departments of Pediatrics and Pathology, Western Reserve University Medical School, Cleveland)

(Received for publication November 11, 1929)

The remarkable power of irradiated ergosterol to prevent or to cure rickets in infants and aimals, first demonstrated for rats by Rosenheim and Webster (1) and Windaus and Hess (2) (3) has been amply confirmed (4) (5) (6) (7). For rats, 0.000,1 mgm. (8) or less (5) (9) and for infants 2 to $4 \mathrm{mgm}$. (5) (10) have proved adequate for cure. If such small amounts produce such striking therapeutic results, the question arises, what are the changes brought about by larger doses.

The effect of excessive doses was first investigated by Pfannenstiel (11) (12) (13), who found that $4 \mathrm{mgm}$. of irradiated ergosterol, in the form of Vigantol, administered by mouth daily, caused rapid loss of weight and death of young rabbits fed on a normal diet. Kreitmair and Moll (14) used a great variety and large numbers of animals, and confirmed Pfannenstiel's findings for the rabbit. In addition they (14) found severe pathological calcification in 100 per cent of rats and cats, in 75 per cent of rabbits and mice, in 15 per cent of dogs, and in only one out of 50 guinea-pigs, but observed no effects, following very large doses, in chickens and in axolotl. They did not study the inorganic composition of the blood nor the changes that precede these advanced pathological conditions. Their conclusion was that the changes were due to hypervitaminosis and that the calcium deposits were a manifestation of metastatic calcification.

The purpose of the present study was to confirm and extend these observations. In addition data were collected to aid in understanding the mechanism by which these changes are brought about. The effect

${ }^{1}$ Read before the American Association of Pathologists and Bacteriologists, Chicago, March 29, 1929, by H. G. and before the American Society for Clinical Investigation in Atlantic City, May 6, 1929, by A. T. S. 
of various diets was evaluated. The duration of administration of ergosterol was varied so that the process could be followed chronologically. The gross and microscopic structure of the soft tissues was examined, the blood serum was analyzed for calcium and inorganic phorhorus, and the bones were x-rayed and analyzed for their content of water, organic matter and ash.

\section{EXPERIMENTAL METHODS}

About 200 piebald black and white rats bred in our laboratory were used. From the time when they were weaned they were fed exclusively on Sherman's diet B, as modified by Smith and Bing (15), which contains 33 per cent of dried whole milk (Klim), 65 per cent whole ground wheat, 0.6 per cent $\mathrm{CaCO}_{3}$ and 0.6 per cent $\mathrm{NaCl}$. Some animals were kept on this diet throughout the entire period of the experiment; others were changed to a diet deficient in either calcium or phosphorus at the age of 4 weeks. The administraion of irradiated ergosterol was begun when the rats were either 4 or 7 weeks old. Roentgenograms were made of most of the animals at the beginning and end of the experimental period. The animals were bled to death under light ether anesthesia. The blood serum was analyzed for calcium by the method of Clark and Collip (16), and for inorganic phosphorus by the method of Briggs (17). Later in the experiment both were determined by the methods of Kuttner and Cohen (18). The amount of ash in the fat free femurs was determined by the method of Chick and Roscoe (19). Autopsies were performed, and all organs except the brain were also examined microscopically. The experiments given in detail were selected as typical.

\section{Experiment I (a)}

The purpose of the first experiment was to study the effect of irradiated ergosterol upon normal young rats fed a normal diet. Six rats (2190 to 2195), 7 weeks old, that had been fed a modification of Sherman's diet B from weaning time, were continued on this diet and given by mouth daily from a pipette $4 \mathrm{mgm}$. of Vigantol, ${ }^{2}$ a commercial

${ }^{2}$ The irradiated ergosterol employed in our experiments was a specially prepared Vigantol, particularly suitable for our work, as it enabled us to give high concentrations in small bulk. We wish to express our thanks for this material to Dr. F. C. Waldecker of the Winthrop Chemical Company, New York City. 
preparation of irradiated ergosterol which contains $10 \mathrm{mgm}$. per cubic centimeter of the oil. The control rats (2180 to 2185), fed upon the same diet, were given as a supplement the same amount of olive oil or $4 \mathrm{mgm}$. of unirradiated ergosterol ${ }^{3}$ in an equal amount of olive oil.

Blood. The results of the chemical anlysis of the blood are given in table 1. The calcium was definitely higher and the inorganic phos-

TABLE 1

Blood serum values following administration of irradiated ergosterol Normal diet; modified Sherman Diet B

\begin{tabular}{|c|c|c|c|c|c|c|}
\hline \multirow{2}{*}{ Rat number } & \multirow{2}{*}{ Age } & \multirow{2}{*}{ Comment } & \multicolumn{2}{|c|}{ Ergosterol } & \multirow{2}{*}{$\mathrm{Ca}$} & \multirow{2}{*}{$\mathbf{P}$} \\
\hline & & & Dose & Period & & \\
\hline & weeks & & $m g m$. & days & $\begin{array}{c}\text { mgm. per } \\
100 \text { cc. serum }\end{array}$ & $\begin{array}{c}\text { mgm. per } \\
100 \text { cc. serum }\end{array}$ \\
\hline $2180-85$ & 8 & Control* & 0 & 0 & 11.8 & 10.8 \\
\hline 2190-95 & 7 & & 4 & 7 & 16.6 & 8.7 \\
\hline 2198-99 & 7 & Control & 0 & 0 & 11.8 & 9.4 \\
\hline $2202-3$ & 7 & & 4 & 1 & 13.2 & 11.6 \\
\hline $22 C 4-5$ & 7 & & 4 & 3 & 13.9 & 11.2 \\
\hline $2206-7$ & 7 & & 4 & 5 & 14.3 & 9.4 \\
\hline 2208-9 & 7 & & 4 & 7 & 14.9 & \\
\hline $2200-1$ & 7 & $\begin{array}{c}\text { Unirradiated } \\
\text { ergosterol }\end{array}$ & 4 & 7 & 11.7 & 9.6 \\
\hline $2228-30$ & 4 & & 2 & 7 & 11.2 & 9.2 \\
\hline $2245-47$ & 4 & & 4 & 2 & & 10.0 \\
\hline $2243-44$ & 4 & & 4 & 3 & 10.9 & 10.7 \\
\hline $2231-33$ & 4 & & 4 & 7 & 10.7 & 9.0 \\
\hline
\end{tabular}

* Same amount of supplement given as olive oil.

phorus slightly lower than in the control rats (2198 and 2199). This is in agreement with the findings of Hess, Lewis and Rivkin (9), and of Klein (20).

Bones. Roentgenograms taken at the end of the experimental period showed a much denser shadow in the ends of the diaphysis of all the long bones of treated rats than that of the controls, a condition described as "hypercalcification" by Hess, Lewis and Rivkin (9).

${ }^{3}$ This was supplied through the kindness of Dr. Charles N. Frey, of the Fleischmann Laboratories, New York City. A test of this preparation by Miss D. N. Smith, showed that 0.0001 to $0.00025 \mathrm{mgm}$. is sufficient, when fed to rats on the Steenbock diet, to protect against rickets. 
Chemical analysis of the bones showed no increase of ash, but instead a normal or decreased content. (See table 2.)

Microscopic examination of sections of the ribs, after fixation in 10 per cent formalin, decalcification in Müller's fluid and staining with hematoxylin and eosin, revealed no striking abnormalities. The zone of provisional calcification was very well defined, the trabeculae of of the primary spongiosa were somewhat slender but abundant and

TABLE 2

Analysis of femur of rats following administration of irradiated ergosterol Normal diet; modified Sherman Diet B. Values in terms of one bone

\begin{tabular}{|c|c|c|c|c|c|c|c|c|}
\hline \multirow{2}{*}{ Rat number } & \multirow{2}{*}{$\begin{array}{c}\text { Age at } \\
\text { beginning }\end{array}$} & \multicolumn{2}{|c|}{ Ergosterol } & \multicolumn{4}{|c|}{ Weight of bone } & \multirow{2}{*}{ Ash } \\
\hline & & Dose & Period & Wet & Dry & Fat free & Ash & \\
\hline & weeks & $m g m$. & days & $m g m$. & $m g m$. & $m g m$. & $m g m$ & $\begin{array}{l}\text { per cent of } \\
\text { fat free }\end{array}$ \\
\hline $2180-85$ & 8 & $0^{*}$ & 0 & 295 & 153 & 149 & 83 & 55.5 \\
\hline $2190-95$ & 7 & 4 & 7 & 309 & 153 & 149 & 81 & 54.2 \\
\hline 2198-99 & 7 & 0 & 0 & 292 & 136 & 128 & 66 & 51.3 \\
\hline $2202-03$ & 7 & 4 & 1 & 306 & 147 & 139 & 74 & 53.3 \\
\hline 2204-05 & 7 & 4 & 3 & 297 & 138 & 130 & 68 & 52.2 \\
\hline $2206-07$ & 7 & 4 & 5 & 282 & 137 & 128 & 67 & 52.8 \\
\hline $2208-09$ & 7 & 4 & 7 & 284 & 142 & 136 & 71 & 52.1 \\
\hline $2200-01$ & 7 & $4 \dagger$ & 7 & 300 & 152 & 147 & 83 & 56.6 \\
\hline $2228-30$ & 4 & 2 & 7 & 144 & 58 & 54 & 22.5 & 41.7 \\
\hline $2231-33$ & 4 & 4 & 7 & 151 & 59 & 56 & 23 & 41.2 \\
\hline $2268-69$ & 4 & 2 & 10 & 213 & 93 & 84 & 33 & 39.4 \\
\hline $2266-67$ & 4 & 1 & 14 & 245 & 109 & 101 & 41.2 & 37.5 \\
\hline 2265 & 4 & 0.5 & 21 & 291 & 147 & 133 & 64 & 48 \\
\hline $2310-11$ & 4 & $0^{*}$ & 0 & 191 & 87 & 83 & 38 & 46.5 \\
\hline
\end{tabular}

* Olive oil for 7 days.

† Unirradiated ergosterol.

very well calcified. Little or no osteoid tissue was present about the trabeculae or cortical bone.

Soft tissues. At autopsy all of the rats presented a striking picture. There was no subcutaneous fat visible and practically no fat in the usual depots. The stomach was small and empty. In the subepicardium and within the myocardium there were abundant white or light yellow, irregular streaks and patches of varying size. The lungs presented no gross abnormalities. The surface of the kidneys was mottled by many small white and light yellow irregular patches and 
streaks of varying size and shape. In the cut surface, throughout the cortex, and especilly at the cortico-medullary junction were many white and light yellow streaks and dots.

After fixation in 10 per cent formalin the tissues were sectioned and stained; some with hematoxylin and eosin, and others with 1 per cent $\mathrm{AgNO}_{3}$, by the Von Kossa method, for the detection of deposits of calcium salts. The results are summarized in table 3.

Microscopic examination of the heart revealed patches of calcification in the myocardium at the site of necrotic muscle fibers, some with, and some without surrounding infiltration of lymphoid cells and infiltration or local proliferation of large mononuclear cells. (See figs. 1 to 3.) The thinner-walled coronary vessels were all calcified in their entire thickness and converted into calcified tubes. (See fig. 4.) In some areas there was only necrosis of myocardium, without calcification, and with or without infiltration and proliferation of large mononuclear cells and infiltration of small lymphoid cells. (See fig. 1.)

In the kidneys severe parenchymatous degeneration with patchy necrosis and calcification of the epithelium of the tubules were the outstanding changes. There was little or no proliferation of histiocytes or infiltration of other cells. The convoluted tubules, especially the distal ones, the loops of Henle and the collecting tubules all showed various degrees of change. The calcification was most abundant at the cortico-medullary junction. The epithelium of many tubules was necrotic, but not calcified. Mitotic figures were moderately abundant in the epithelial cells, especially of the convoluted tubules. A varying number of the interlobular and afferent arteries were the seat of calcification throughout the entire thickness of their wall. The glomeruli and Bowman's capsules were unaffected. (See figs. 5 to 7 .)

In the muscularis of the stomach, pathological manifestations exactly like those of the myocardium occurred. In the mucosa, necrosis and patchy calcification of the glands was very severe in most of the animals, but little or no infiltration of cells occurred. (See figs. 8 and 9.)

In one animal the cartilage of a bronchus near the hilus of the lungs was calcified, and in another, the bronchial epithelium was necrotic and partly calcified. Kreitmair and Moll described calcification in 


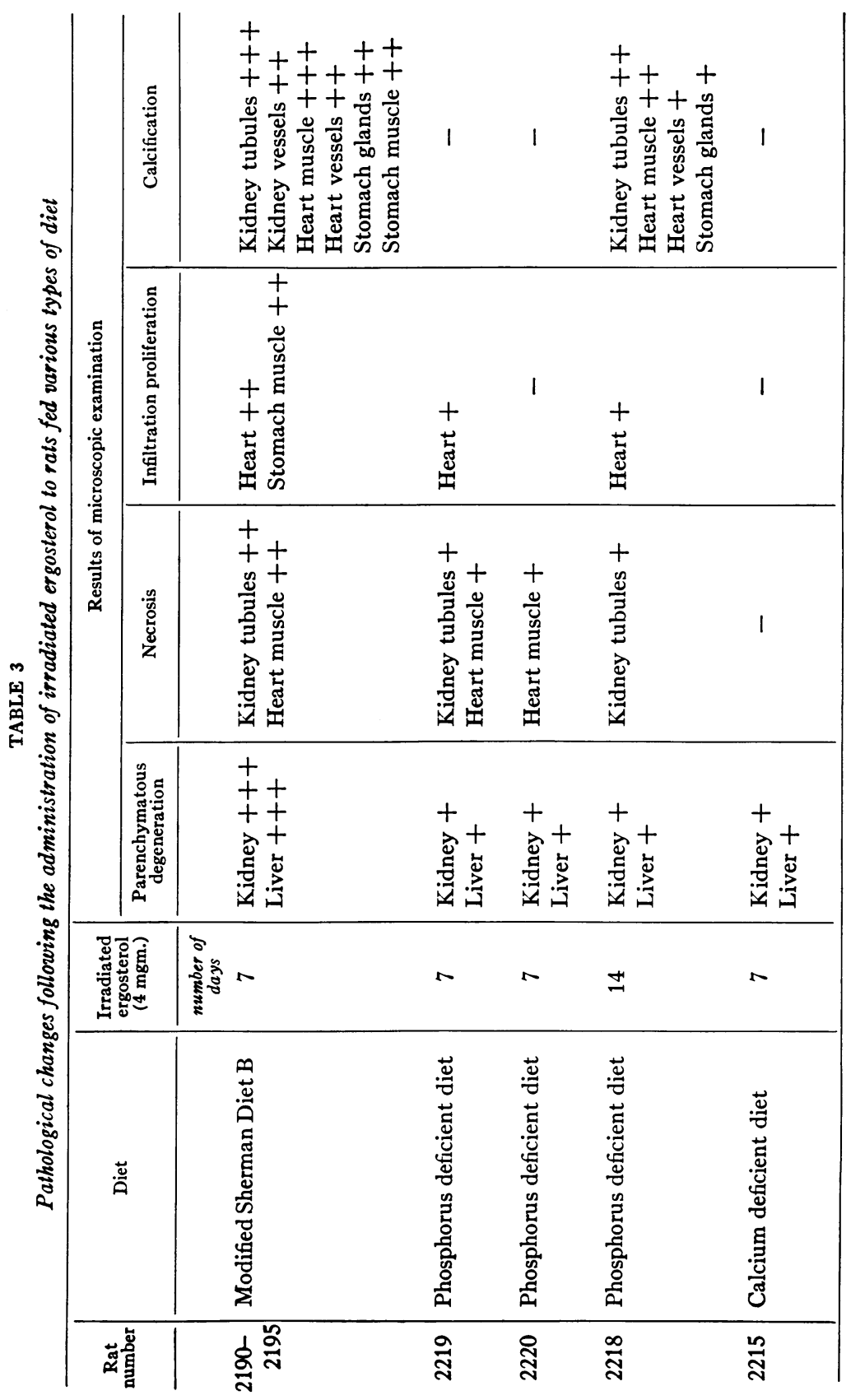


A. T. SHOHL, H. GOLDBLATT AND H. B. BROWN

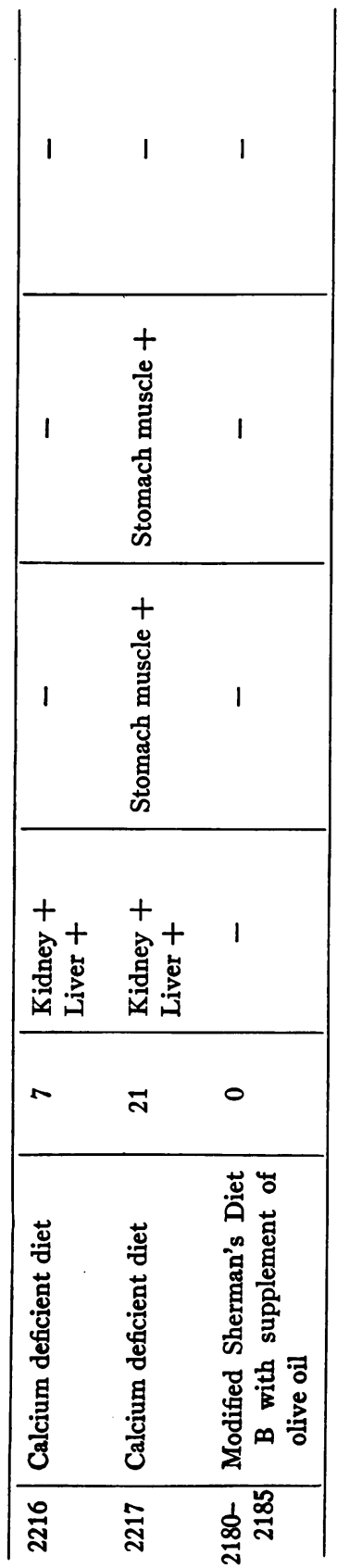


the lungs, but we did not observe any in this group of rats. However, in another experiment, calcification was found in both bronchial bronchiolar and alveolar walls.

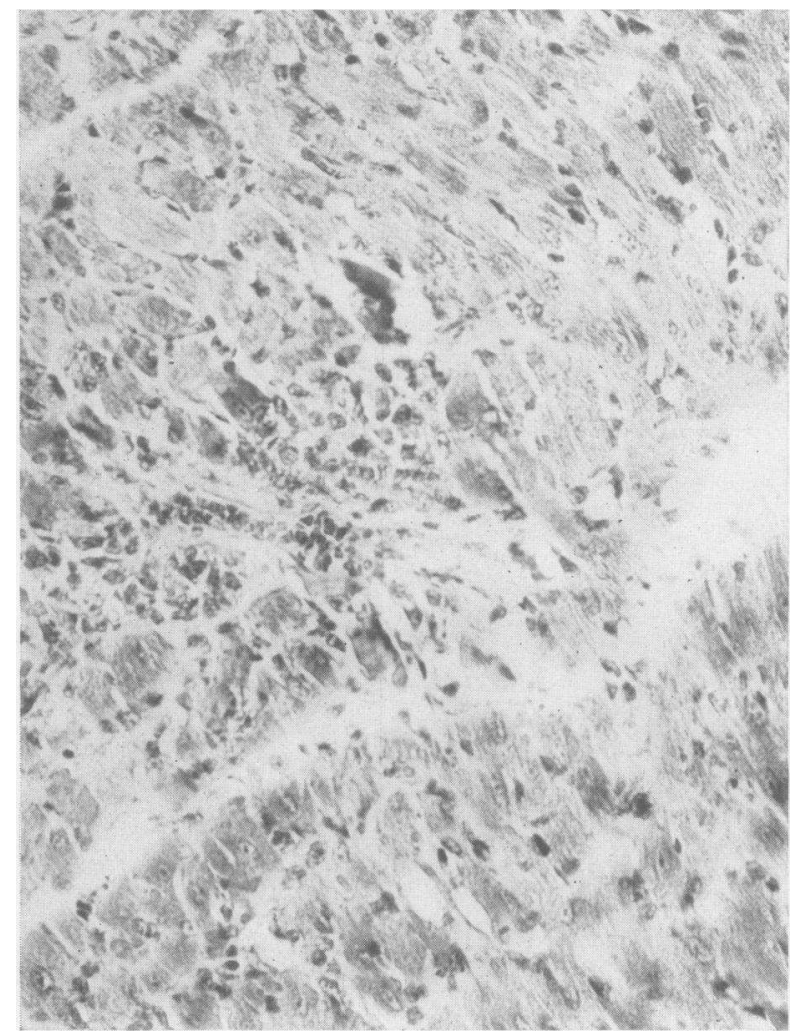

FIG. 1. Sherman diet B (normal). Irradiated ergosterol 4 mgm. 5 days. Heart: H. \& E. stain. Necrosis of myocardium. Proliferation and infiltration of large and small mononuclear cells. One small patch of calcification.

In the adrenals of one animal calcification was observed in the medulla.

The liver showed advanced diffuse parenchymatous degeneration, patchy necrosis and signs of regeneration, for mitotic figures were moderately abundant (figs. 10 and 11); but no calcification was observed in this organ. 
In the intestine, pancreas, testis, ovary, thyroid, parathyroid and thymus no striking changes occurred and calcification was not observed.

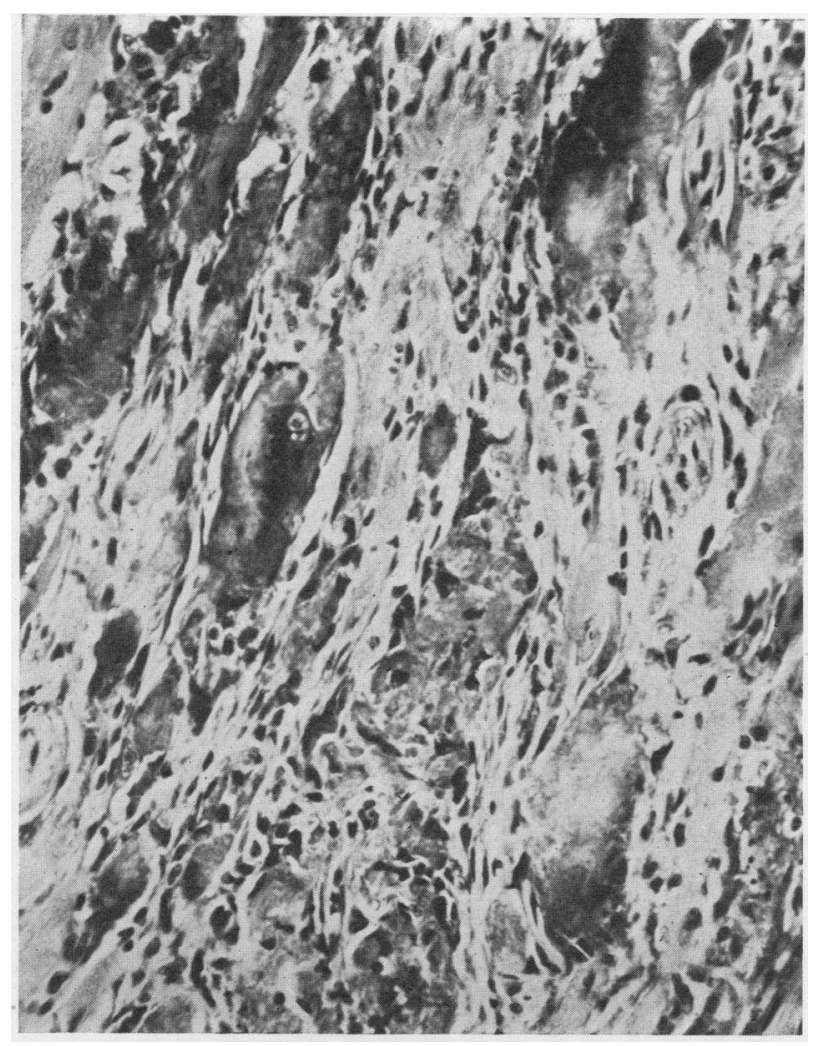

Fig. 2. Sherman diet B. Irradiated ergosterol $4 \mathrm{mgm} .7$ days. Heart: H. \& E. stain. Necrosis, infiltration, proliferation and severe calcification.

In the control rats (2180 to 2185 ) which received a suplement of olive oil only, no microscopic abnormalities were seen. Calcification was not observed in any organs of the control rats.

\section{Experiment $I(b)$}

Similar procedures with animals at the age of 4 weeks (2228 to 2233) showed that the younger animals died sooner on a smaller dose, $2 \mathrm{mgm}$., 
and that on a mgm. the pathological changes were even more severe in some rats than those recorded above in older animals.

These results confirm those of Kreitmair and Moll (14) that irradiated ergosterol given to normal animals causes severe pathological

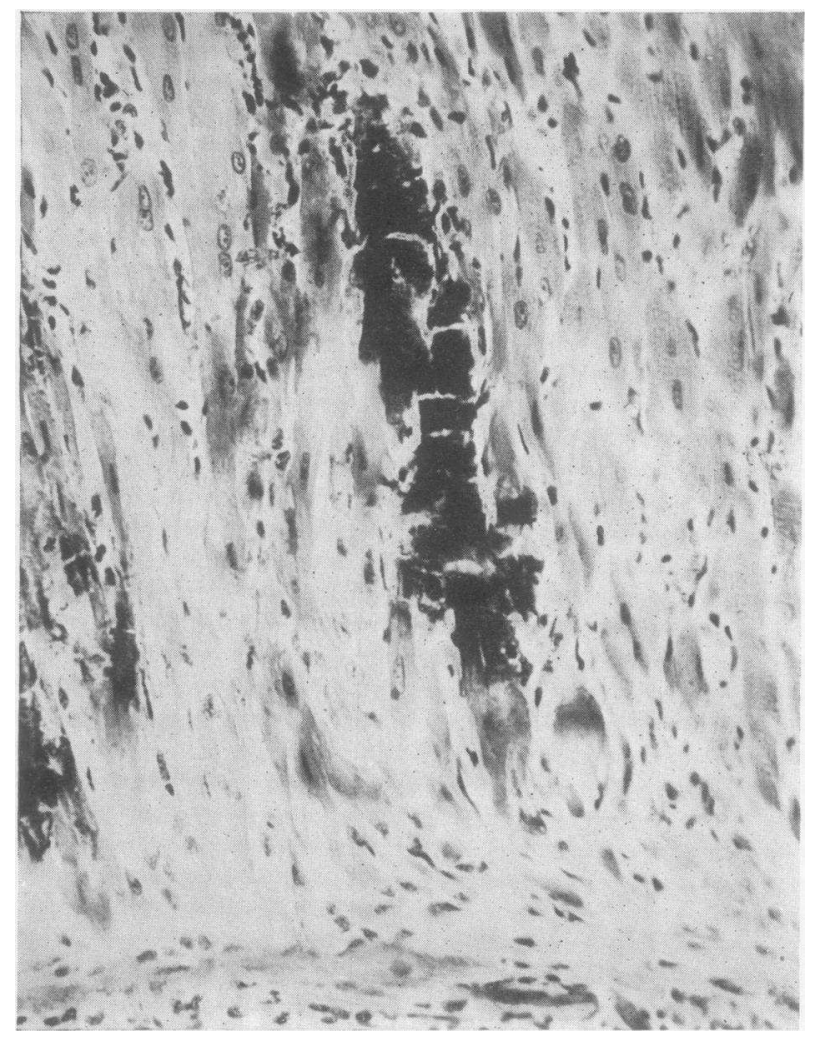

Fig. 3. Sherman diet B. Irradiated ergosterol $4 \mathrm{mgm} .7$ days. Heart: Von Kossa and H. \& E. stains. Necrosis and calcification of myocardium.

calcification. In addition, chemically, demineralization of the bones was found.

\section{Experiment I (c)}

To determine whether the pathological changes such as necrosis, infiltration and proliferation precede, accompany or follow the calci- 
fication, or are merely a manifestation of metastatic calcification, the following experiment was performed.

As in experiment I (a), rats were fed on Sherman's diet B from the time of weaning to the end of the experimental period. Of a single

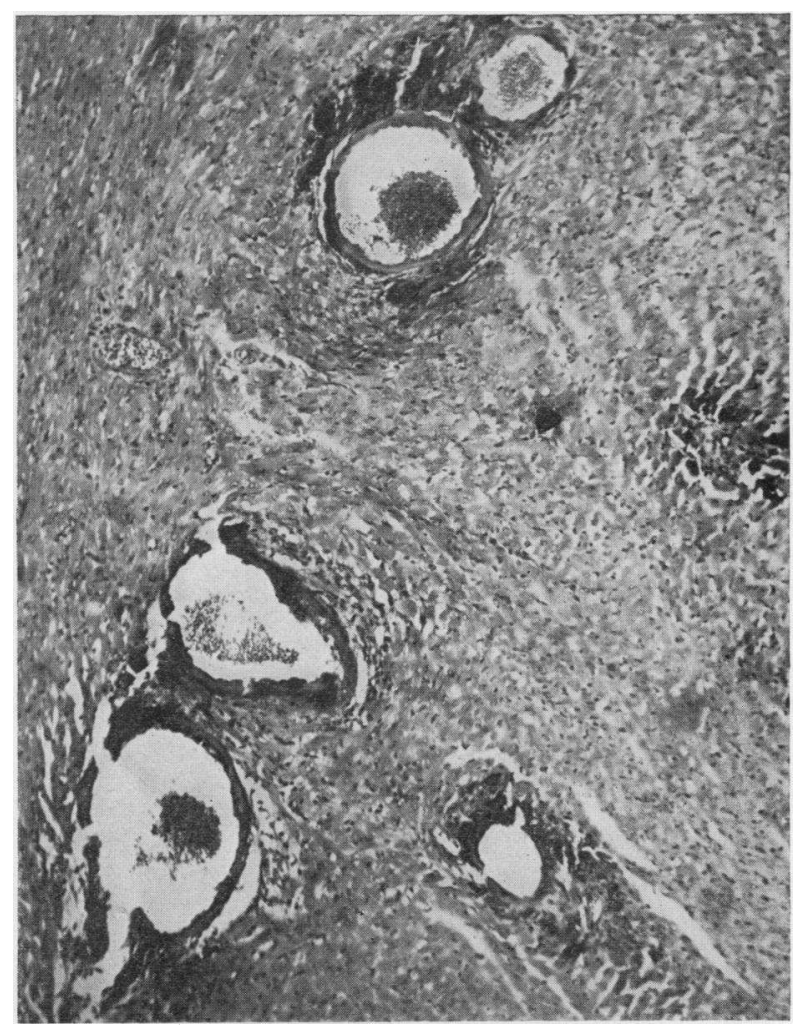

Fig. 4. Sherman diet B. Irradiated ergosterol 4 mgm. 7 days. Heart: Coronary vessels converted into completely calcified tubes. Patchy calcification of myocardium.

litter of twelve rats, at the age of 7 weeks, two rats (2198 and 2199) were killed as controls. Two additional controls (2200 and 2201) received $4 \mathrm{mgm}$. of unirradiated ergosterol daily for 7 days. To the remaining eight rats (2202 to 2209) $4 \mathrm{mgm}$. of irradiated ergosterol 
were administered daily and groups of two animals were sacrificed after $1,3,5$ and 7 days. Anorexia and loss of weight set in on the first day.

Blood. In table 1, the results of the chemical analyses of the blood are given. The calcium of the serum of all of the rats that received irradiated ergosterol (2202 to 2209) was higher than that of the two

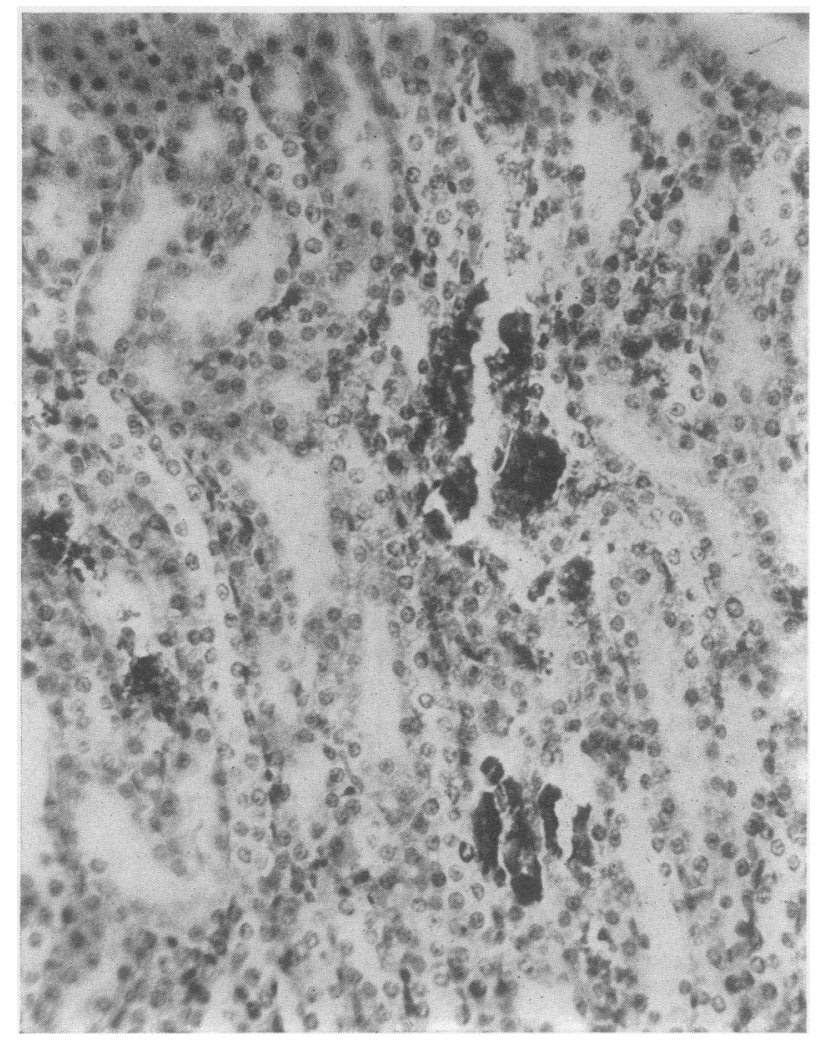

Fig. 5. Sherman diet B. Irradiated ergosterol 4 mgm. 3 days. Kidney: H. \& E. stain. Slight patchy calcification of tubular epithelium.

controls (2198 and 2199) sacrificed at the beginning of the experiment and of the two (2200 and 2201) which received $4 \mathrm{mgm}$. of unirradiated ergosterol for 7 days. The values for the two types of controls were practically the same. In the rats (2202 to 2205) killed after 1 and 3 days of irradiated ergosterol the inorganic phosphorus was increased, 
but in the two (2206 and 2207) on the fifth day the value was normal. as was also the case for animals that received irradiated ergosterol for 7 days (2190 to 2195$)$.

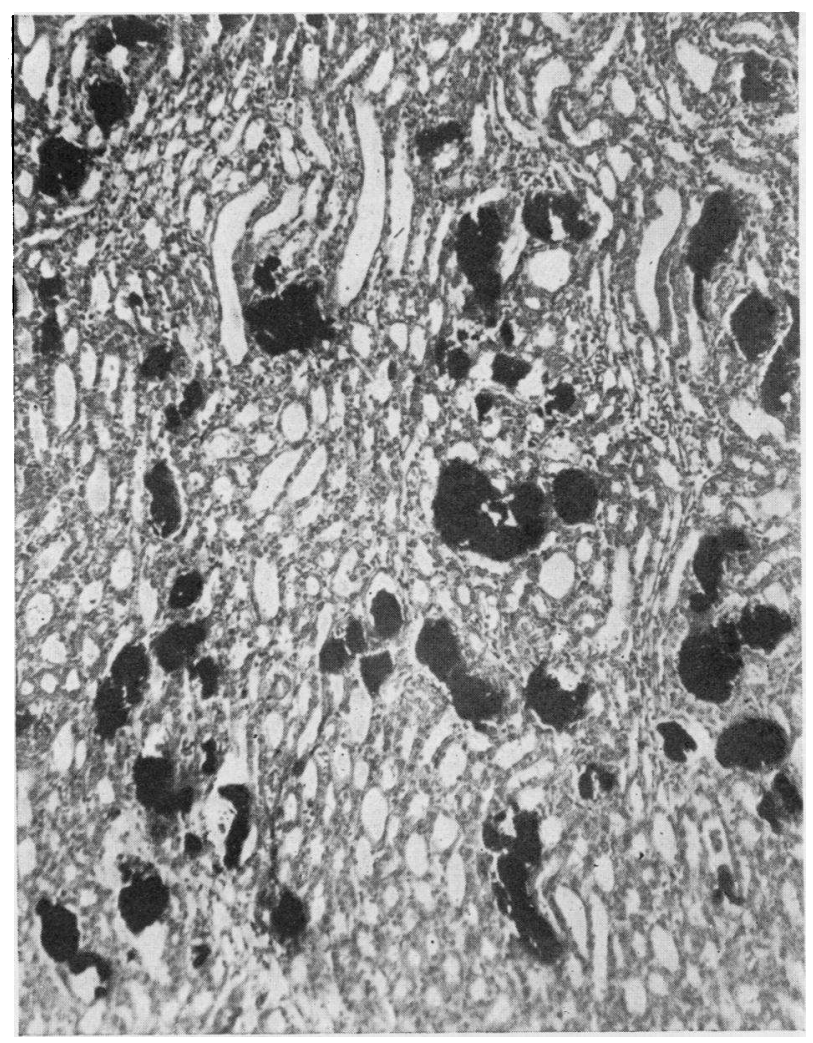

FIG. 6. Sherman diet B. Irradiated ergosterol $4 \mathrm{mgm} .7$ days. Kidney: Von Kossa and H. \& E. stains. Severe patchy calcification of tubular epithelium.

Bones. Roentgenograms of those rats which had received irradiated ergosterol showed definite hypercalcification of the ends of the long bones on the third day.

The values for the ash content of the bones (table 2) were lower than those of the controls (2200 and 2201) which received unirradiated ergosterol. Microscopically, the ribs resembled those of experiment I (a). 
Soft tissues. The pathological findings are summarized in table 4. The control rats which received no supplement, and were killed at the beginning of the experiment, showed no pathological changes. In the control rats that received $4 \mathrm{mgm}$. of unirradiated ergosterol for 7 days, the only change was slight cloudy swelling of kidneys and liver. After

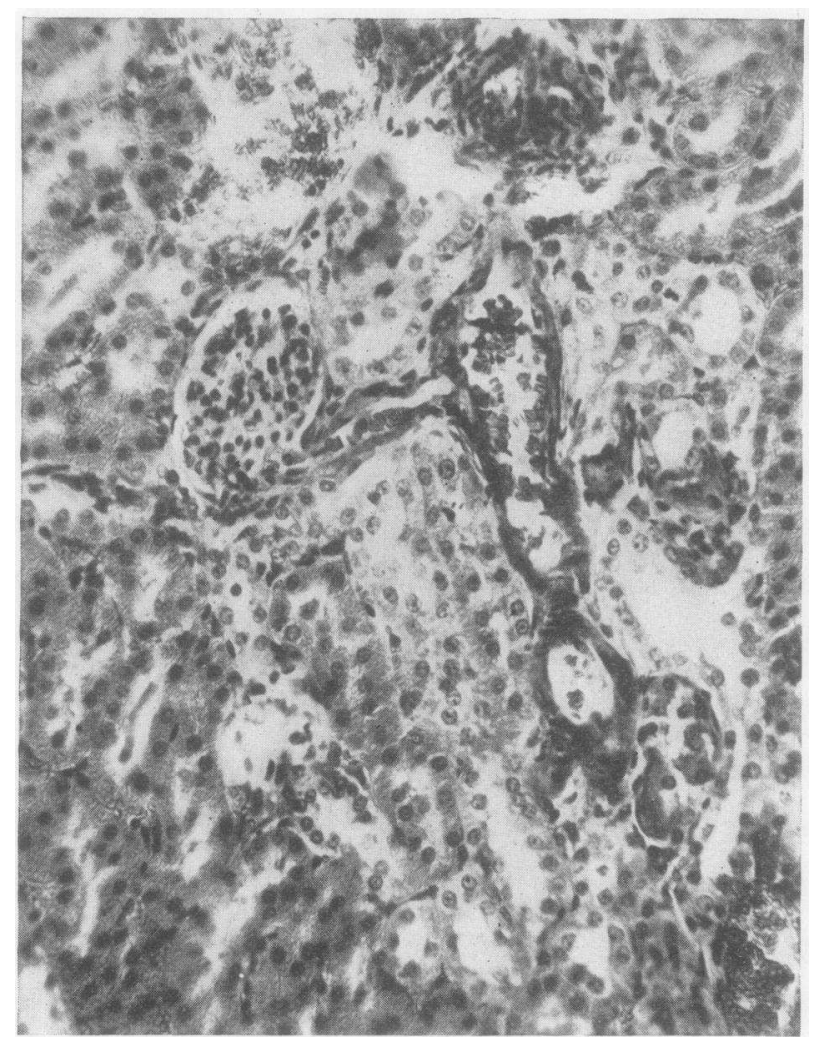

FIG. 7. Sherman diet B. Irradiated ergosterol 4 mgm. 7 days. Kidney: H. \& E. stains. Calcification of interlobular and afferent vessels. Glomerulus intact.

one day of irradiated ergosterol (rats 2202 and 2203), moderate cloudy swelling of liver and kidneys was the only microscopic abnormality observed. In the two rats (2204 and 2205) that received irradiated ergosterol for 3 days the parenchymatous degeneration of liver and kidneys was more severe. There was a moderate amount of 
necrosis of the lining epithelium, especially of the distal convoluted tubules. Calcification of necrotic epithelium of a few distal convoluted tubules was observed. The calcification was greater in the kidneys of rat 2205 than in those of rat 2204.

In the rats (2206 and 2207) that received irradiated ergosterol for 5 days the above changes were more severe and, in addition, necrosis of single myocardial fibers, and bundles of fibers, and moderate patchy calcification of heart muscle, kidney tubules and stomach

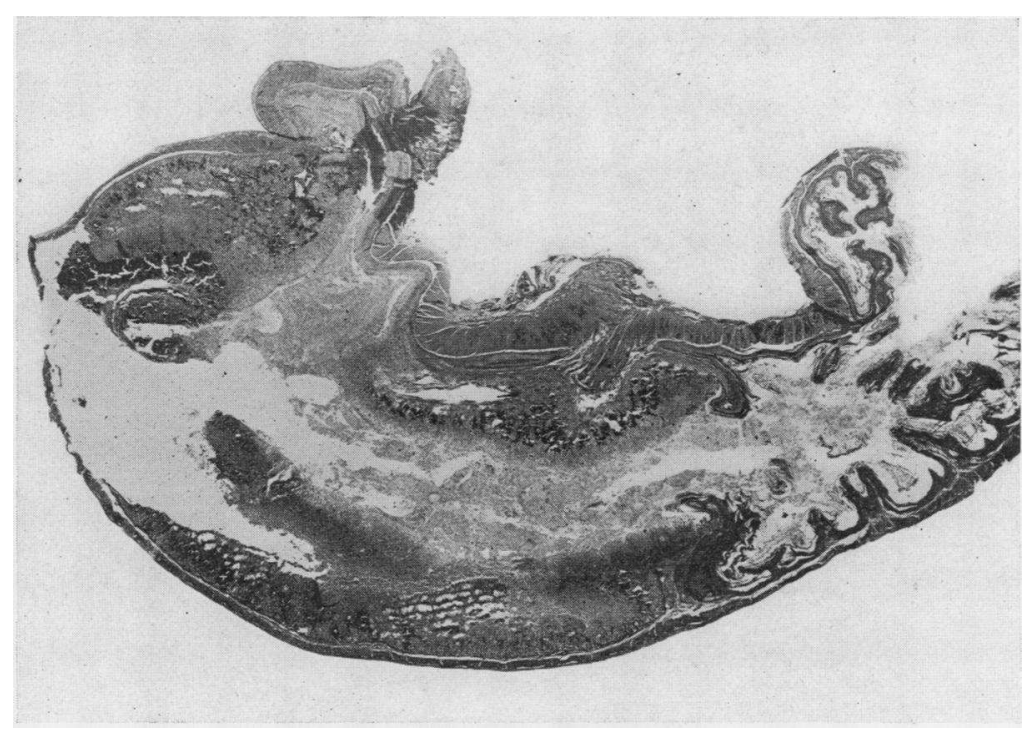

Fig. 8. Sherman diet B. Irradiated ergosterol $4 \mathrm{mgm} .7$ days. Stomach: Von Kossa and H. \& E. stains. Severe calcification of mucosa. Moderate calcification of muscularis.

muscle were present. In the myocardium and in the muscularis of the stomach were patches of interstitial infiltration or proliferation of large mononuclear cells and infiltration of small lymphoid cells intimately associated with necrotic muscle fibers.

Rats 2208 and 2209 which had received irradiated ergosterol for 7 days, showed the same changes as those which had received it for $\mathbf{5}$ days. Calcification and necrosis in kidneys, heart and stomach were more extensive, and exactly like those of the rats in experiment I (a). 
Five rats (2243 to 2247), four weeks old, fed on modified Sherman's diet $B$ and given a daily supplement of $4 \mathrm{mgm}$. of irradiated ergosterol, were killed at intervals. After 2 and 3 days, only parenchymatous degeneration of liver and kidneys with signs of regeneration (mitoses)

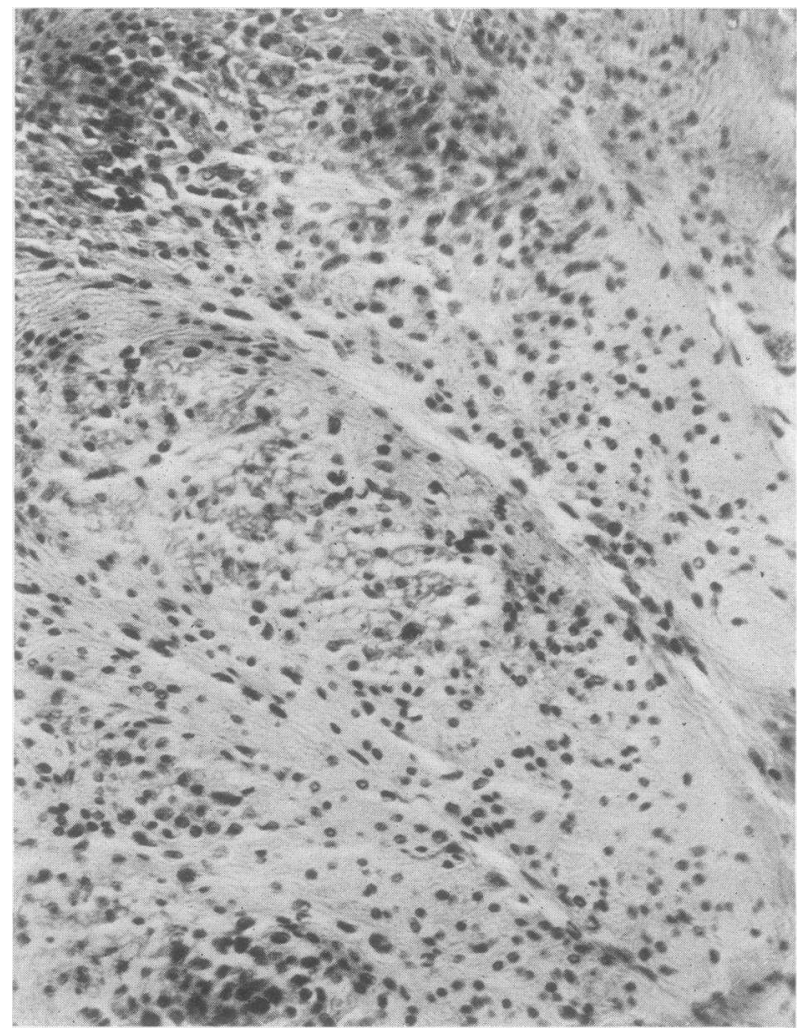

Fig. 9. Calcium deficient diet. Irradiated ergosterol $4 \mathrm{mgm} .21$ days. Stomach: Von Kossa and H. \& E. stains. Necrosis of muscularis. Proliferation and infiltration of large and small mononuclear cells.

were observed in the liver. After 4 days calcification appeared but was less severe than in the older animals.

Thus when the changes were observed chronologically, it became evident that irritative and toxic phenomena preceded calcification. 


\section{Experiment II}

To determine what are the changes induced by excess of irradiated ergosterol in rats fed diets deficient in calcium or phosphorus, and which inhibit normal calcification of bones, the following experiments were performed.

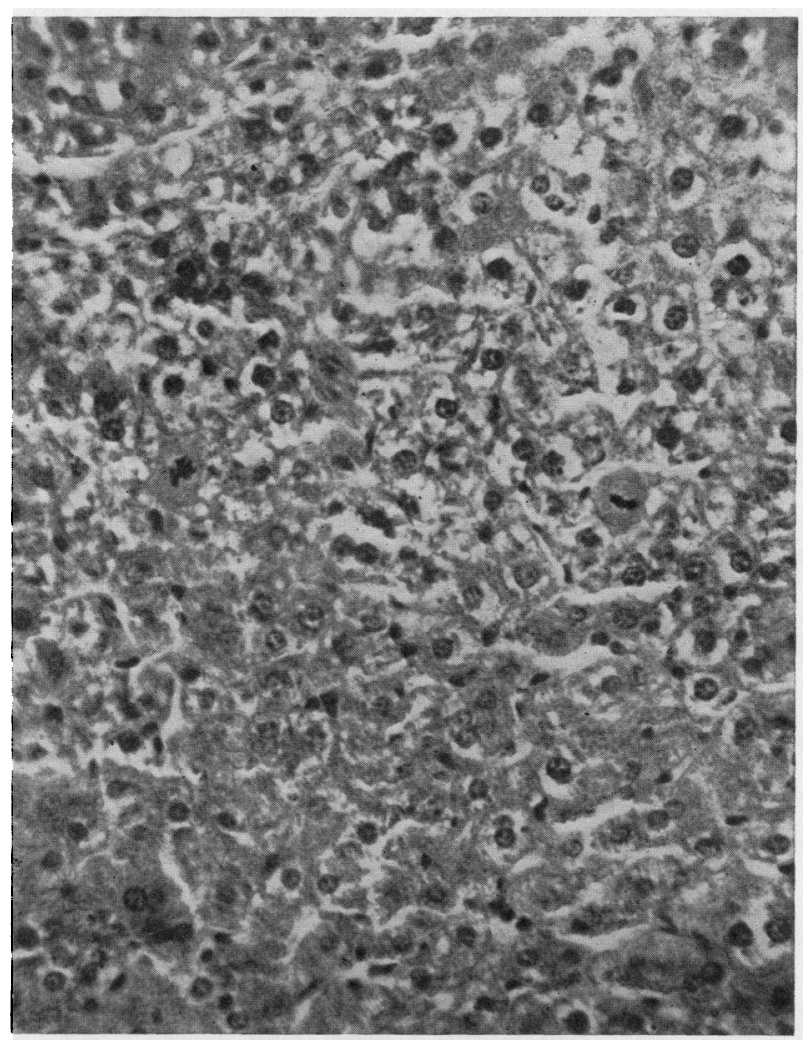

Fig. 10. Sherman diet B. Irradiated ergosterol 4 mgm. 7 days. Liver: H. \& E. stain. Severe parenchymatous degeneration. Signs of regeneration.

(a) Phosphorus-deficient diet. Three rats 4 weeks old were fed until 7 weeks old on Steenbock and Black's (21) low phosphorus and high calcium rickets-producing diet number 2965. Then $4 \mathrm{mgm}$. of irradiated ergosterol were administered daily for 7 days to two of the rats (2219 and 2220), and for 14 days to one rat (2218). Anorexia and loss 
of weight were progressive throughout the experimental period but the rats lived.

Blood. Chemical analysis of the blood (see table 5) showed that the calcium was higher in the groups that received irradiated ergosterol (2175 to 2180 ) than in groups of rachitic control rats (2170 to 2174)

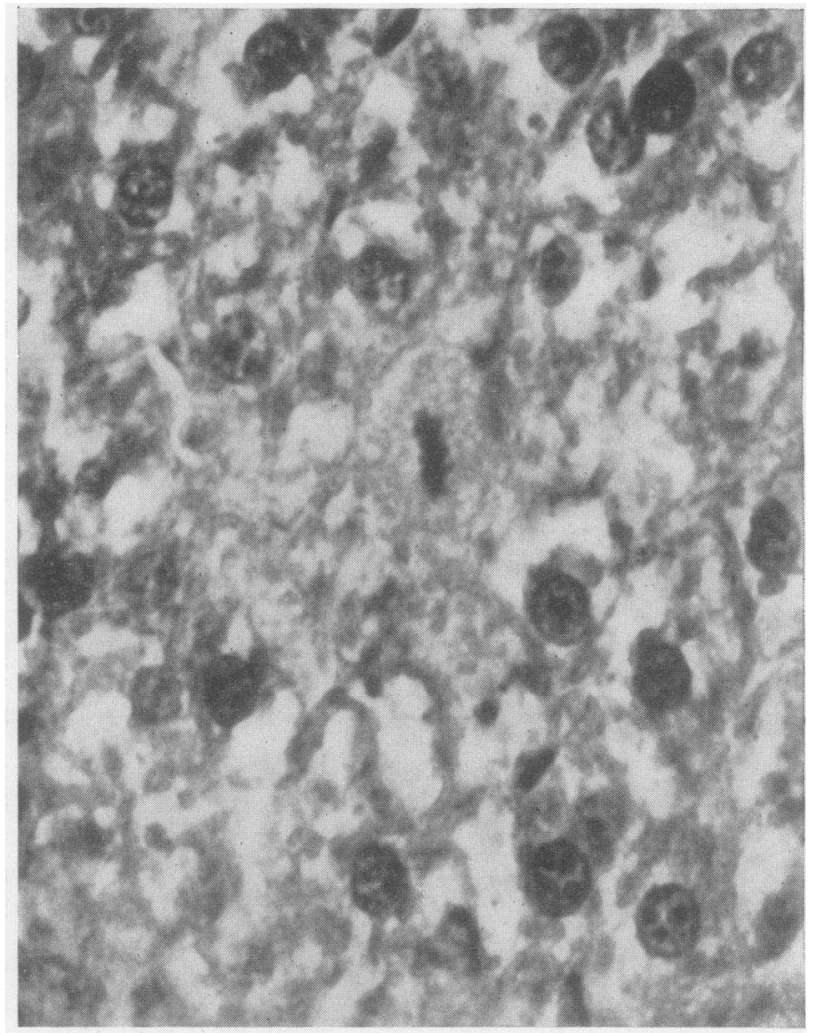

Fig. 11. Same as fig. 10, showing mitosis

fed on the same diet. The phosphorus was about normal and therefore much higher than that usual in untreated rats fed on this ricketsproducing diet.

Bones. Roentgenograms showed no rickets. The epiphyseal ends of the diaphysis of the long bones were hypercalcified.

After administration for two weeks of $2 \mathrm{mgm}$. irradiated ergosterol 
(2175 to 2180), the ash content was the same as that of the rachitic control rats one week younger (table 6). Therefore healing had taken place without increase in the mineral content of the femur.

Microscopically, the radius and ribs of the three rats (2218 to 2220) presented the picture of healed rickets; the zone of provisional calcification was irregular but very well defined, the zone of hypertrophic cartilage varied in thickness from 3 to 10 cells in the same bone; the trabeculae at the site of what was previously the rachitic metaphysis were irregular in shape and varied in size, but were well calcified; and osteoid tissue, though present, was not excessive around either trabeculae or cortex.

Soft tissues. With the exception of parenchymatous degeneration of kidneys and liver, one of the two rats which received irradiated ergosterol for 7 days showed no pathological changes; the other showed, in addition, necrosis of kidney epithelium and of myocardial fibers. The rat (2218) that was treated for 14 days showed parenchymatous degeneration of kidneys and liver; necrosis and infiltration of kidney, heart and stomach; and calcification of the tubules of the kidneys, of the vessels and muscle fibers of the heart, and of the mucosa of the stomach. The heart muscle is shown in figure 12. The degree of change was approximately that of the animals of experiment I (c), that ate a normal diet and had received irradiated ergosterol for 5 days (rats 2206 and 2207). The rachitic rats were more resistant than the normals to the effects of irradiated ergosterol. However, similar changes were induced. The rickets was promptly healed. The blood phosphorus was elevated. The bones healed without an increase or even despite a decrease in the mineral content.

(b) Calcium deficient diet. Three rats 4 weeks old were fed for 3 weeks on a low calcium diet consisting of Steenbock and Black's diet number 2965 with the $\mathrm{CaCO}_{3}$ omitted and 2.5 per cent of $\mathrm{Na}_{2} \mathrm{HPO}_{4} 12 \mathrm{H}_{2} \mathrm{O}$ added. At the age of 7 weeks the daily administration of $4 \mathrm{mgm}$, of irradiated ergosterol was begun. Two rats (2215 and 2216) received it for one week and one (2217) for three weeks. Anorexia soon set in and loss of weight continued throughout the experimental period.

Blood. Chemical analysis of the blood (table 5) showed normal or slightly high values for calcium. This was, however, a great increase 


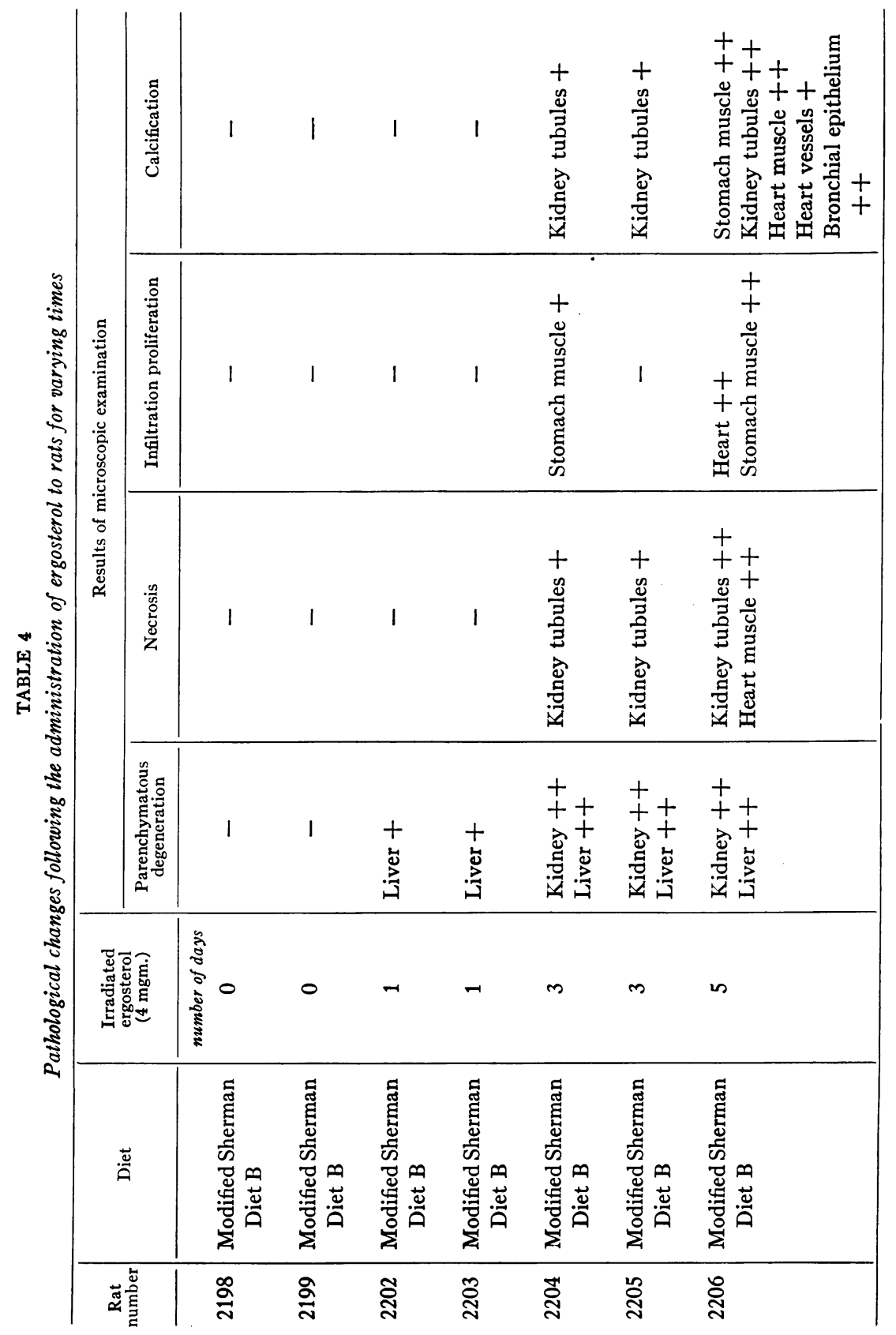


A T. SHOHL, H. GOLDBLATT AND H. B. BROWN

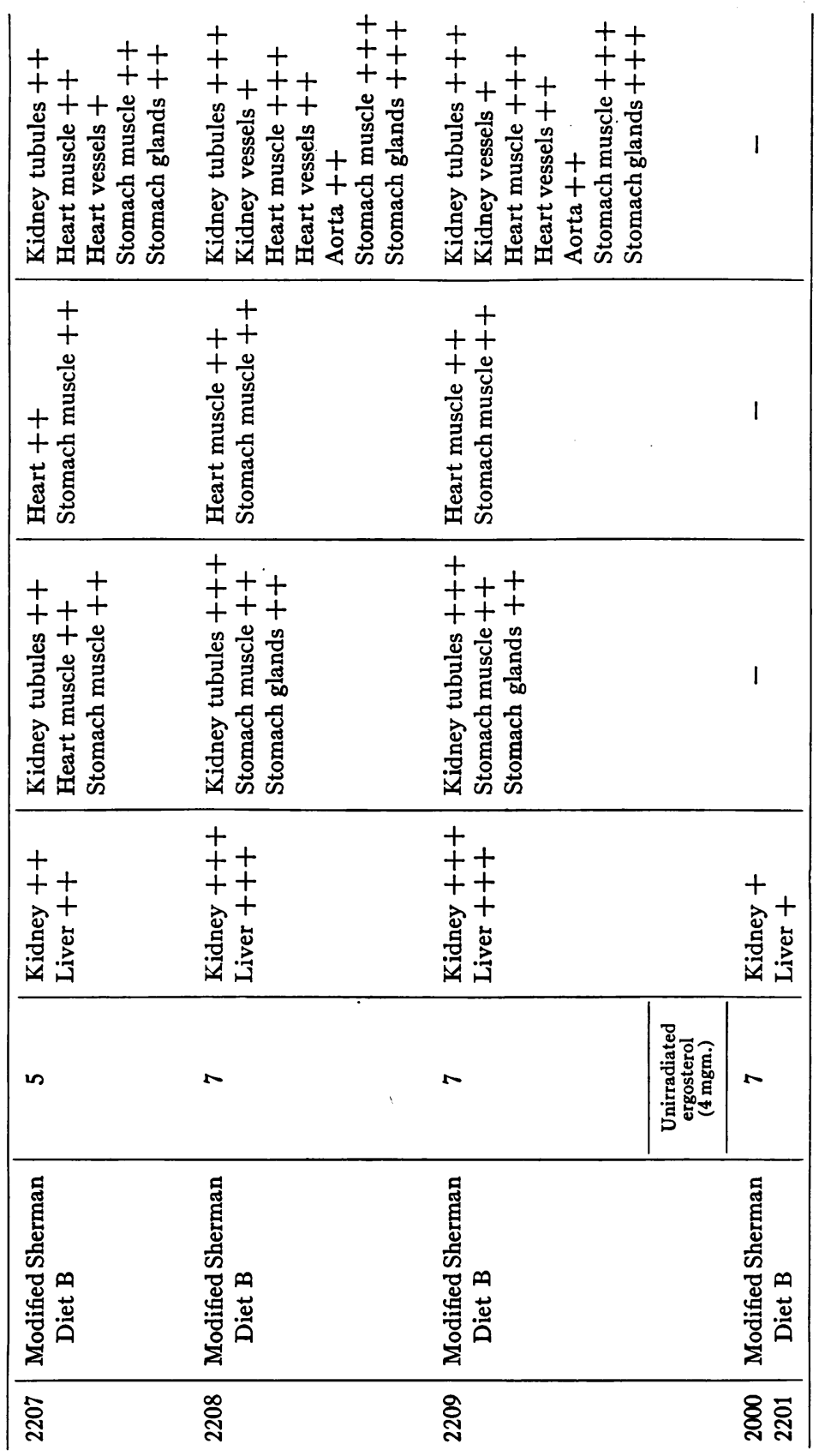


TABLE 5

Calcium and inorganic phosphorus in the blood serum of rats following administration of irradiated ergosterol

\begin{tabular}{|c|c|c|c|c|c|c|}
\hline \multirow{2}{*}{ Rat number } & \multirow{2}{*}{$\begin{array}{l}\text { Diet from age } \\
\text { of } 4 \text { weeks }\end{array}$} & \multirow{2}{*}{ Age } & \multicolumn{2}{|c|}{ Ergosterol } & \multirow{2}{*}{$\mathrm{Ca}$} & \multirow{2}{*}{$\mathbf{P}$} \\
\hline & & & Dose & Period & & \\
\hline & & weeks & $m g m$. & days & $\begin{array}{c}\text { mgm. per } 100 \\
\text { cc. serum }\end{array}$ & $\begin{array}{c}\text { mgm. per } 100 \\
\text { cc. serum }\end{array}$ \\
\hline $2170-74$ & $\begin{array}{c}\text { Phosphorus } \\
\text { deficient }\end{array}$ & 7 & 0 & 0 & 11.2 & 3.2 \\
\hline $2175-80$ & $\begin{array}{c}\text { Phosphorus } \\
\text { deficient }\end{array}$ & 7 & 2 & 14 & 15.0 & 6.6 \\
\hline 2218 & $\begin{array}{c}\text { Phosphorus } \\
\text { deficient }\end{array}$ & 7 & 4 & 14 & 13.2 & 6.0 \\
\hline $2219-20$ & $\begin{array}{c}\text { Phosphorus } \\
\text { deficient }\end{array}$ & 7 & 4 & 7 & 13.8 & 8.8 \\
\hline $2234-36$ & $\begin{array}{c}\text { Phosphorus } \\
\text { deficient }\end{array}$ & 4 & 2 & 7 & 11.0 & 8.3 \\
\hline $2210-12$ & $\begin{array}{l}\text { Calcium } \\
\text { deficient }\end{array}$ & 9 & 0 & 0 & 6.1 & 9.4 \\
\hline 2213-14 & $\begin{array}{l}\text { Calcium } \\
\text { deficient }\end{array}$ & 7 & 0 . & 0 & 8.1 & 8.2 \\
\hline $2215-16$ & $\begin{array}{l}\text { Calcium } \\
\text { deficient }\end{array}$ & 7 & 4 & 7 & 11.5 & 10.2 \\
\hline 2217 & $\begin{array}{l}\text { Calcium } \\
\text { deficient }\end{array}$ & 7 & 4 & 21 & 12.2 & 8.8 \\
\hline
\end{tabular}

TABLE 6

Analysis of femur of rats following administration of irradiated ergosterol

Values in terms of one bone

\begin{tabular}{|c|c|c|c|c|c|c|c|c|c|}
\hline \multirow{2}{*}{$\begin{array}{c}\text { Rat } \\
\text { number }\end{array}$} & \multirow{2}{*}{ Diet } & \multirow{2}{*}{$\begin{array}{c}\text { Age at } \\
\text { beginning }\end{array}$} & \multicolumn{2}{|c|}{ Ergosterol } & \multicolumn{4}{|c|}{ Weight of bone } & \multirow{2}{*}{ Ash } \\
\hline & & & Dose & Period & Wet & Dry & Fat free & Ash & \\
\hline & & weeks & $m g m$. & days & $m g m$. & $m g m$. & $m g m$. & $m g m$. & $\begin{array}{l}\text { per cent } \\
\text { of fat free }\end{array}$ \\
\hline $2175-80$ & $\begin{array}{c}\text { Phosphorus } \\
\text { deficient }\end{array}$ & 7 & 2 & 14 & 203 & 86 & 79 & 32.5 & 41.1 \\
\hline $2170-74$ & $\begin{array}{c}\text { Phosphorus } \\
\text { deficient }\end{array}$ & 8 & 0 & 0 & 260 & 112 & 90 & 28 & 31.1 \\
\hline $2100-6$ & $\begin{array}{c}\text { Phosphorus } \\
\text { deficient }\end{array}$ & 9 & 0 & 0 & 240 & 107 & 90 & 28 & 31.0 \\
\hline 2213-14 & $\begin{array}{l}\text { Calcium } \\
\text { deficient }\end{array}$ & 7 & 0 & 0 & 302 & 148 & 131 & 61 & 46.5 \\
\hline $2215-16$ & $\begin{array}{l}\text { Calcium } \\
\text { deficient }\end{array}$ & 7 & 4 & 7 & 300 & 149 & 117 & 52 & 44.4 \\
\hline
\end{tabular}


when compared to that of two control groups of rats (2213 and 2214) and (2210 to 2212) fed on the same diet, without irradiated ergosterol, for 3 and 5 weeks respectively: in these the serum calcium was very low. In the two rats (2215 and 2216) that received irradiated ergos-

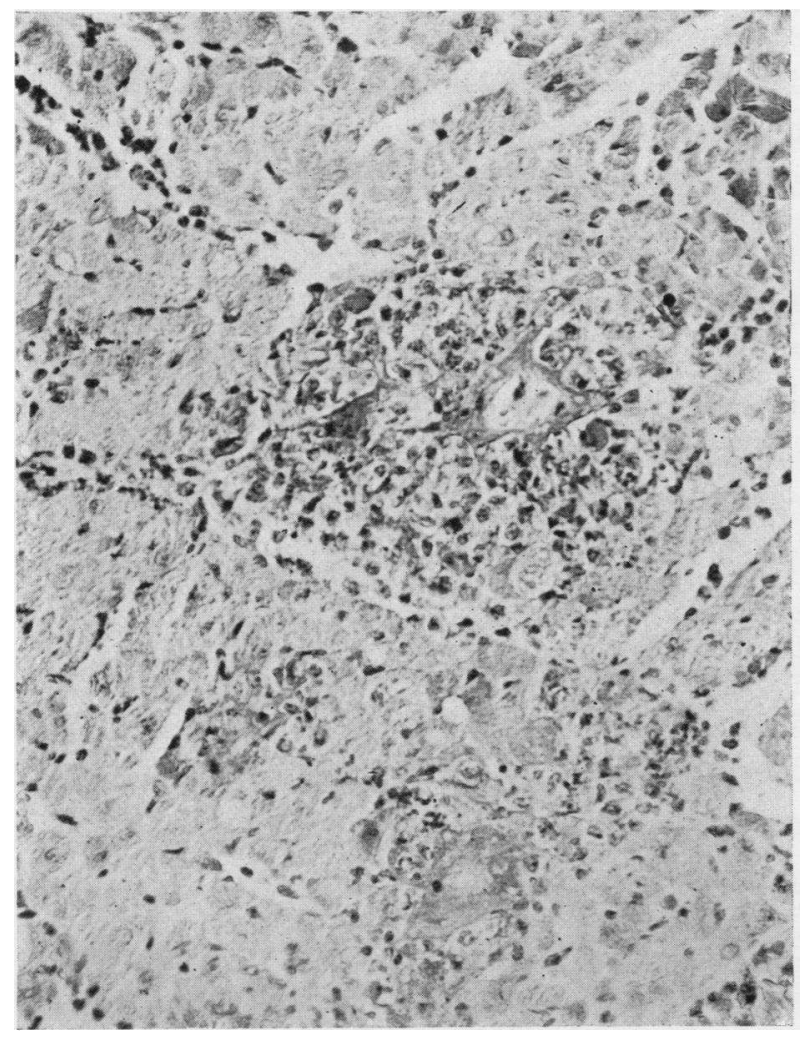

FIG. 12. Phosphorus deficient diet (rickets-producing). Irradiated ergosterol 4 mgm. 14 days. Heart: H. \& E. stain. Necrosis of myocardium. Proliferation and infiltration of large and small mononuclear cells. No calcification.

terol for 1 week the inorganic phosphorus was increased compared to that of the controls but was about equal to that of normal rats. In the one rat (2217) that received it for 3 weeks the value was equal to that of the controls, that is, lower than that of rats fed on a normal diet. 
Bones. Roentgenograms showed no evidence of rickets in either the controls or those that were given irradiated ergosterol. The shaft of the bones appeared rarified. There was no evidene of hypercalcification in either group.

The amount of ash in the bones of the control rats fed on the calcium deficient diet alone was low compared with the normal. In those that received irradiated ergosterol for 7 days, though the rats were one week older, the values were even lower. (See table 6.)

Microscopically, the ribs showed no signs of rickets. In the primary spongiosa the trabeculae were present in moderate number. They were calcified but partly cartilaginous and thin. The zone of provisional calcification was well calcified. Cortical bone was thin but well calcified and there was no demonstrable osteoid tissue.

Soft tissues. With the exception of parenchymatous degeneration of kidneys and liver the two rats that received irradiated ergosterol for one week showed no pathological changes. In the one that was treated for 3 weeks necrosis, and infiltration and proliferation of small and large mononuclear cells occurred in the muscularis of the stomach; no calcification was observed in any of the organs.

These rats were more resistant to irradiated ergosterol than any others studied. The bones as a whole showed lack of mineralization. The blood serum calcium was definitely raised.

\section{DISCUSSION}

Because the amount of calcium in the serum of rats fed on a normal diet, or on diets deficient in phosphorus or calcium, is very distinctly above normal, the possibility that one is dealing merely with metastatic calcification and not with a toxic effect must be considered. Metastatic calcification is not the sole cause, for a toxic effect is indicated by the fact that $(a)$ severe parenchymatous degeneration and necrosis occurred in the liver, where no calcium was deposited; (b) parenchymatous degeneration and necrosis as well as proliferation, and infiltration of inflammatory cells preceded calcification in such organs as heart, kidney and stomach. (c) In the liver and kidneys signs of epithelial regeneration (mitoses) accompanied the degeneration and necrosis, which is additional evidence of a toxic effect of the Vigantol, for it is a common manifestation of recognized toxic elements. 
Whether it is the antirachitic substance in irradiated ergosterol which has this toxic effect or some other irradiated product present as an impurity in Vigantol, is being investigated. Pathological calcification occurred mainly in organs in which so-called "metastatic calcification" usually manifests itself, and, since hypercalcemia was present, the deposition of calcium salts was probably due in part to this process.

\section{SUMMARY AND CONCLUSIONS}

The oral administration of 2 to $4 \mathrm{mgm}$. of irradiated ergosterol in the form of Vigantol to rats 4 to 7 weeks old, fed on a normal diet, resulted in loss of weight and death in 5 to 14 days. Roentgenograms disclosed increased density at the epiphyseal ends of the diaphysis of the long bones after 3 to 4 days. The calcium of the blood serum was definitely raised and the inorganic phosphorus slightly lowered. The bones showed lack of mineralization and even slight but definite demineralization.

Parenchymatous degeneration, necrosis, inflammatory infiltration and proliferation and calcification occurred in various organs of the body, but mainly in tubules and vessels of kidney, muscle and vessels of heart and muscularis and mucosa of stomach. Calcification also appeared with moderate frequency in the lungs and aorta, and rarely in the adrenals. The pathological findings indicate that irritative and toxic processes were associated with the calcification. Whether they always preceded the deposition of calcium salts cannot be stated. The toxic effects were due either to the irradiated ergosterol or to an irradiated impurity in the Vigantol. The deposits of calcium salts were probably in part a manifestation of so-called "metastatic calcification."

In rats fed on diets deficient in either calcium or phosphorus, calcification occurred but was less severe and delayed. However, the degenerative changes and necrotizing effects were as severe as in animals fed on a normal diet.

The healing of rickets which occurred in these rats, in the presence of overdosage of the therapeutic agent, was associated with deposition of calcium in the metaphysis; but analysis of the whole femur showed that the mineral content was normal or even diminished. Lack of mineralization or even demineralization of the shaft must have occurred. Therefore rickets may be healed by a rearrangement and not a retention of calcium and phosphorus in the bones. 


\section{BIBLIOGRAPHY}

1. Rosenheim, O., and Webster, T. A., Biochem. J., 1926, xx, 537. The Antirachitic Properties of Irradiated Sterols.

2. Windaus, A., and Hess, A. F., Nachr. d. Gesellsch. d. Wissensch. zu Göttingen Math-physik. Kl., 175, Heft 2, 1926, Sitzung 28 Jan. 1927. Sterine und Antirachitisches Vitamin.

3. Hess, A. F., and Windaus, A., Proc. Soc. Exp. Biol. and Med., 1927, xxiv, 461. The Development of Marked Activity in Ergosterol Following UltraViolet Irradiation.

4. Windaus, A., and Holtz, F., Nachr. d. Gesellsch. d. Wissensch. zu Göttingen Math-physik. Kl., 217, 1927. Die experimentelle Rattenrachitis und ihre Beziehung zum Ergosterin.

5. Hottinger, A., Ztschr. f. Kinderh., 1927, xliv, 282. Untersuchungen über bestrahltes Ergosterin. Beiträge zur indirekten Lichttherapie der rachitischen Knochenkrankheiten am Tier, beim Kind und am Erwachsenen.

6. Hess, A. F., and Windaus, A., Proc. Soc. Exper. Biol. and Med., 1926, xxiv, 369. Contaminating Substances as a Factor in the Activation of Cholesterol by Irradiation.

7. Hess, A. F., J. Am. Med. Assoc., 1927, lxxxix, 337. Antirachitic Activity of Irradiated Cholesterol, Ergosterol and Allied Substances.

8. Rosenheim, O., and Webster, T. A., Biochem. J., 1927, xxi, 389. The Parent Substance of Vitamin D.

9. Hess, A. F., and Lewis, J. M., J. Am. Med. Assoc., 1928, xci, 783. Clinical Experience with Irradiated Ergosterol.

10. György, P., Klin. Wchnschr., 1927, vi, 580. Therapeutische Versuche mit bestrahltem Ergosterin.

11. Pfannenstiel, W., Med. Klin., 1927, xxiii, 1913. Discussion.

12. Pfannenstiel, W., Münch. Med. Wchnschr., 1928, lxxv, 1113. Weitere Beobachtungen über Wirkungen bestrahlten Ergosterins im Tierversuch.

13. Pfannenstiel, W., Lancet, 1928, ii, 845. A Summary of Recent Work on Vigantol (Irradiated Ergosterol).

14. Kreitmair, H., and Moll, T., Munch. Med. Wchnschr., 1928, lxxv, 637 and 1113. Hypervitaminose nach grossen Dosen Vitamin D.

15. Smith, A. H., and Bing, F. C., J. Nutrition, 1928, i, 179. Improved Rate of Growth of Stock Albino Rats.

16. Clark, E. P., and Collip, J. B., J. Biol. Chem., 1925, lxiii, 461. A Study of the Tisdall Method for the Determination of Blood Serum Calcium with a Suggested Modification.

17. Briggs, A. P., J. Biol. Chem., 1924, lix, 255. Some Applications of the Colorimetric Phosphate Method.

18. Kuttner, T., and Cohen, H. R., J. Biol. Chem., 1927, 1xxv, 517. Micro Colorimetric Studies. I. A Molybdic Acid, Stannous Chloride Reagent. The 
A. T. SHOHL, H. GOLDBLATT AND H. B. BROWN

Micro Estimation of Phosphate and Calcium in Pus, Plasma, and Spinal Fluid.

19. Chick, H., and Roscoe, M. H., Biochem. J., 1926, xx, 137. The Anti-rachitic Value of Fresh Spinach.

20. Klein, I. J., J. Am. Med. Assoc., 1929, xcii, 621. Effects of Massive Doses of Irradiated Ergosterol.

21. Steenbock, H., and Black, A., J. Biol. Chem., 1925, lxiv, 263, (See p. 274). Fat Soluble Vitamins. XXIII. The Induction of Growth Promoting and Calcifying Properties in Fats and Their Unsaponifiable Constituents by Exposure to Light. 